\title{
Do Exchange Rates Affect the Profitability of Multinational Companies? Evidence from China and the USA
}

\author{
Nan Wang*, Bin Tang \\ Center for Experimental Economics in Education (CEEE), Shaanxi Normal University, Xi'an, China.
}

How to cite this paper: Nan Wang, Bin Tang. (2021) Do Exchange Rates Affect the Profitability of Multinational Companies? Evidence from China and the USA. Journal of Humanities, Arts and Social Science, 5(1), 47-68.

DOI: $10.26855 /$ jhass.2021.01.007

Received: January 5, 2021

Accepted: January 31, 2021

Published: February 8, 2021

"Corresponding author: Nan Wang, Center for Experimental Economics in Education (CEEE), Shaanxi Normal University, Xi'an, China.

Email: wangnanceee@163.com

\begin{abstract}
The impact of exchange rates on profitability of Multinational Companies is a puzzling and interesting question towards different regional data and relevant issues. This essay has discussed the relationship between exchange rates and profitability. Three perspectives regarding open economy and exchange rates have been employed by us to observe this issue theoretically. First perspective: from the perspective of international trade; Second perspective: from the perspective of decision-making; Third perspective: from the perspective of risk. The data that we collected came from Top 30 Multinational Companies in China and the USA. The required data elements are the value of each company's rate of ROE, ROCE, EPS and the average annual exchange rates, Gross Domestic Product (GDP) annual growth rates, lending interest rates of China and the USA. From the previous literature and our results, it is reasonable to conclude that the impact of exchange rate changes on profitability is not significant for Top30 MNCs based on China and the USA. Many multinational companies will hedge foreign exchange rate risk by using various financial instruments. The article also reveals the multinational company profitability varies from the domestic regimes and company individuality.
\end{abstract}

\section{Keywords}

Exchange rate, Trade, Decision-making, Risk

\section{Introduction}

The impacts of exchange rates on profitability of Multinational Companies (MNCs) have been observed by a range of researchers; nonetheless, different approaches and dimensions bring to various conclusions and it still remains to be a puzzling and interesting question towards different regional data and relevant issues. This essay aims to analyse whether exchange rates affect MNCs on the basis of literature and data from China and the USA. It has been well-organised with the following structure: first, theoretical analyses from perspectives of trade, decision-making and risk will be made; and then, this paper will select Top $30 \mathrm{MNCs}$ in China and the USA as samples to examine the relationship between exchange rates and profitability via a model; finally, the implications of models and discussion will be explored soundly and reasonably.

\section{Theoretical analysis}

Whether exchange rates affect MNCs has aroused heated discussion. This question can be explored from two aspects: whether exchange rates affect profitability or not; how it exerts the impacts. Empirically, exchange rates do 
affect the profitability of MNCs. Three perspectives regarding open economy and exchange rates have been employed by us to observe this issue theoretically.

\subsection{From the perspective of international trade}

International trade determines large extent of the profitability of multinational companies if firms focus on foreign market. Even those companies benefit mostly from domestic market, the volume of international trade still be a decisive indicator to indicate the performance of operating activities in MNCs. Straightforwardly, the volume of international trade directly matters with the profitability of MNCs.

After the period of stability of exchange rate under Bretton-Woods systems, volatility of exchange rates generated a fierce debate about how it affects the international trade in reality. The factors affecting international trade business may include the following aspects: policy factors, cultural environment factors and market environment factors (Zhengyan, 2018).

The impact of exchange rate changes on enterprise profits is heterogeneous in different types of enterprise ownership, industry competition and import intermediate trade intensity (Shuo \& Dandan, 2019). Mundell (1961) says trade flows stabilize real exchange rate fluctuations, thus reducing real exchange volatility. Broda (2003) procedures a model of two-sided trade to evaluate the effect on trade of exchange rate volatility and exchange rate regimes such as fixed exchange rate and currency boards by disaggregate data. The result indicates that real exchange rate volatility depresses trade in differentiated goods.

But Broll and Eckwert (1999) have the opposite thought. They assume industries are able to react flexibly to changes of international exchange rate so they can simply reallocate their products in different markets. Based on previous assumption, they estimate that positive correlations between volumes of industry-specific export and exchange rate volatility in countries where firms get profit from a large domestic market. The market structure makes the export no longer crucial. The larger uncertainty of the exchange rate will add the value of the export as firms have domestic markets. Hence, it stimulates the firm's production activity. However, change of exchange rate brings higher risk exposure for firms. This may decrease the production and volume of international trade. The net impact depends on the degree of relative risk aversion of the firm.

\subsection{From the perspective of decision-making}

In order to examine how the exchange rate influence MNCs, Sung and Lapan (2000), Xie and Du (2007) built the model called "two countries-two corporations" to testify the influence of exchange rate on MNCs. $V_{i, j}\left(\sigma_{e}^{2}\right)=E\left[\Pi_{i, j}(e)\right], U_{i, j}\left(\sigma_{e}^{2}\right)=E\left[\pi_{i, j}(e)\right]$ have been adopted to calculate to the relationship between exchange rate and value in the model. When exchange rates change, the variation of the exchange rate will affect the strategy of multinational and domestic enterprises. We can get conclusion regarding exchange rates and profitability as follows:

1. Generally, multinational companies' decision-making will be conducted either in domestic investment or in two countries at the same time. And the host companies get higher return than multinational companies when they choose not to produce.

2. When domestic firms in host country produce products, as the increase of the variations on exchange rate, the change of profit on domestic firms in host country shows (Sung \& Lapan, 2000): (1) when multinational firms only produce at home, profit increases; (2) when multinational firms only produce at foreign country, profit remains unchanged; (3) when the multinational firms produce in both countries, the profit decreases.

\subsection{From the perspective of risk}

"Exchange rates are the amount of one country's currency needed to purchase one unit of another currency (Brealey, 1999, p. 625)". People will not pay too much attention to the exchange rate fluctuations when they are intending to exchange some money for the trips. However, for MNCs, their transactions will involve large amounts of money; the waves of a foreign currency could indicate "getting a surplus or a deficit on the balance sheets" (StudyMode, 2002). Therefore, the exchange rate risk can influence the multinational company profitability.

Exchange rate risk mainly includes the following: one is transaction risk, which refers to the change of actual cash flow payment caused by the uncertainty of exchange rate for the foreign currency transactions or the creditor's rights and debts held by enterprises. It can be divided into cash flow risk and exchange risk. The other is economic risk, 
which refers to the change of international competitiveness of enterprises caused by unexpected exchange rate changes in the process of production and operation, which affects the future income and cash flow of enterprises, and further affects the internal value of enterprises (Jinfu, 2020). Transaction risk is a kind of liquidity risk, which is mainly reflected in the exchange rate changes during the period of goods and debt settlement. Economic risk is more focused on macroeconomic analysis, from the perspective of the whole enterprise to predict the future cash flow changes in a certain period. Because of the fluctuation of foreign exchange rate, it is a potential possibility that the company's future earnings become very uncertain. Potential economic risk is directly related to the company's overseas operation effect, and will cause changes in the enterprise's operation, business, product and other decisions, such as product quantity, market positioning, etc., resulting in changes in revenue (Ye, 2020).

Another type of exchange rate risk that MNCs cannot neglect is translation risk. It is the possibility of changes in the company balance sheets caused by the changes of foreign exchange rate. It may impact the result of the company's financial report. Therefore, the translation risk can influence the profit figures on accounting.

\section{Methodology and Data}

\subsection{Methodology}

To access the impact of exchange rate uncertainty on the profitability of MNCs, we employ ordinary least squares (OLS) methods (Gujarati \& Porter, 2009) to estimate the significance of the hypothesized independent variables on profitability of multinational firms. We track a similar analysis of methodology adopted by Lee et al. (2012), Oskooee et al. (2009), and Faff et al. (2005). EPS, ROE and ROCE regarded as the main indicators to measure the profitability of MNCs are involved in a multi-factor experiment, with the experimental factors like exchange rate, GDP and interest rate corresponding to the factors hypothesized to influence profitability. We estimate the impact of exchange rate changes on profitability in China \& USA with regression models:

1. $E P \hat{S}=C_{1}+\alpha_{1} E X+\alpha_{2} G D P+\alpha_{3} I R+\varepsilon_{i}$

2. $R O \hat{E}=C_{2}+\beta_{1} E X+\beta_{2} G D P+\beta_{3} I R+\varepsilon_{i}$

3. $R O C \hat{E}=C_{3}+\gamma_{1} E X+\gamma_{2} G D P+\gamma_{3} I R+\varepsilon_{i}$

\subsection{Economic Approach to Measuring Profitability}

In this study, we decide to measure foreign operations' profitability by Return on equity (ROE), Return on capital employed (ROCE) and Earnings per Share (EPS). According to these important indicators (Appendix II), the listed companies are measured and the profitability of a company's capital investment is examined.

\begin{tabular}{|c|c|c|}
\hline & Advantage & Disadvantage \\
\hline $\mathrm{ROE}$ & $\begin{array}{l}\text { 1. Comparison } \\
\text { ROE connect earnings data and become } \\
\text { relevant measurements that can be } \\
\text { compared across sectors. } \\
\text { 2.Ease of Calculation } \\
\text { Investors can easily collect the } \\
\text { information from a company's financial } \\
\text { statements including balance sheet and } \\
\text { net income. }\end{array}$ & $\begin{array}{l}\text { 1. Subjectivity } \\
\text { As net income is defined as revenues } \\
\text { minus expenses, expenses are subject } \\
\text { to many manipulations on the } \\
\text { company's accounting policies like } \\
\text { depreciation. } \\
\text { 2. The complementation between two } \\
\text { indicators is not strong. } \\
\text { Asset size of listed companies are not } \\
\text { equal, it should not assess its } \\
\text { effectiveness and management degree } \\
\text { by the enterprise income indicators on } \\
\text { absolute value. }\end{array}$ \\
\hline
\end{tabular}




\begin{tabular}{|c|c|c|}
\hline ROCE & $\begin{array}{l}\text { 3.Comparison } \\
\text { ROCE can be used to compare } \\
\text { performance with other divisions and } \\
\text { companies. Also it is fair to divisions } \\
\text { with different sizes of investment }\end{array}$ & $\begin{array}{l}\text { 1.Ignores the time value of money } \\
\text { ROCE does not take the time value of } \\
\text { money into account. } \\
\text { 2.No general agreement about how } \\
\text { capital employed should be } \\
\text { calculated. Therefore, the method } \\
\text { permit the decision maker to choose a } \\
\text { definition of ROCE that suits their } \\
\text { preconception of a project's } \\
\text { desirability most. }\end{array}$ \\
\hline EPS & $\begin{array}{l}\text { 1.Ease of Calculation } \\
\text { Investors can easily collect the } \\
\text { information from a company's financial } \\
\text { statements including balance sheet and } \\
\text { net income. } \\
\text { 2.Avoid the subjective factors } \\
\text { EPS can reflect the company's } \\
\text { profitability and investment risk } \\
\text { objectively without the influence of } \\
\text { behavioral factors like risk averse and } \\
\text { confidence. }\end{array}$ & $\begin{array}{l}\text { Ignores the time value of money } \\
\text { EPS does not take the time value of } \\
\text { money into account, which might lead } \\
\text { to one-sided pursuit of profit } \\
\text { maximization and a variety of } \\
\text { short-term behavior of enterprises }\end{array}$ \\
\hline
\end{tabular}

Lee and Suh (2009) use return on equity (ROE) as measurement to examine the impact of exchange rate changes on Multinational companies' profitability before accessing the effects of financial hedging. While several analytic forecasting models on earning per share done by Johnson and Schmitt (1974) indicated that econometric factors should substantially improve so that investors could rely on judgment and experience to predict the firm's profit.

\subsection{Data}

According to the regression model that has been established in this article, the required data elements are the value of each company's rate of ROE, ROCE, EPS and the average annual exchange rates, Gross Domestic Product(GDP) annual growth rates, lending interest rates of China and the USA.

Based on the formulas of ROE and ROCE, there are six kinds of data about company's financial situation required to be collected totally. To ensure the accuracy of the data, all the figures are gathered from the annual report which downloaded from each company's official website.

In the analysis of Chinese MNCs' profitability, in order to be more close to reality situation, the purchasing power parity (PPP) of Chinese Yuan (RMB) is used instead of the exchange rates, which are acquired from the International Monetary Fund (IMF) database. Since Canada is the largest trading partner of the United States, the exchange rate between the U.S. dollar and the Canadian dollar will be more representative in the analysis of American MNCs. The USD-to-CAD annual rates are obtained from Bank of Canada's website.

The Chinese GDP annual growth rates and lending rates are collected from the database of China's National Bureau of Statistics. However, the United States does not have fixed lending rates; therefore the U.S. prime lending rate is used in the regression model which is got from the database of Royal Bank of Canada. The figure of U.S. GDP annual growth is found in report of the U.S. Department of Commerce. 


\section{Empirical Results and Discussion}

\subsection{Empirical Results}

Six models have been regressed and their results have been presented in Figures 1-6 and as follows.

$$
\begin{aligned}
& E P \hat{S}=-1.447+0.349 E X+6.925 G D P+15.351 I R \\
& \mathrm{Se}:(8.278) \quad(1.110) \quad(48.452) \quad(58.011) \\
& t:[-0.175] \text { [0.314] [0.143] [0.265] } \\
& R O \hat{E}=-0.180+0.027 E X+2.014 G D P+0.535 I R \\
& \text { Se:(0.267) (0.036) (1.561) (1.869) } \\
& t:[-0.676] \text { [0.769] [1.291] [0.286] } \\
& R O C \hat{E}=0.040-0.014 E X+0.341 G D P+1.485 I R \\
& \mathrm{Se}:(0.345) \quad(0.046) \quad(1.999) \quad(2.378) \\
& t:[0.117] \quad[-0.307] \quad[0.170] \quad[0.624] \\
& E P \hat{S}=1534.487-1422.075 E X-1882.373 G D P+369.2418 I R
\end{aligned}
$$

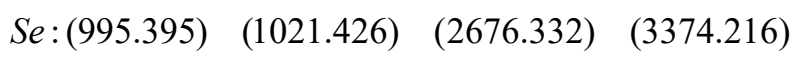

$$
\begin{aligned}
& t:[1.542] \quad[-1.392] \quad[-0.703] \text { [0.109] } \\
& R O \hat{E}=0.752-0.349 E X-0.315 G D P-2.370 I R \\
& \mathrm{Se}:(1.719) \quad \text { (1.764) (4.622) (5.83) } \\
& t:[0.438] \quad[-0.197] \quad[-0.068] \quad[-0.407] \\
& R O C \hat{E}=-24.895+25.893 E X+6.619 G D P-37.404 I R \\
& \text { Se:(19.634) (20.148) (52.791) (66.556) } \\
& t:[-1.268] \quad[1.285] \quad[0.125] \quad[-0.562]
\end{aligned}
$$

Figures 1-3[(1) (2) (3)] and figures 4-6 [(4) (5) (6)] shows the relationship between profitability (EPS, ROE, and ROCE) and independent variables (including EX, GDP and IR) in terms of MNCs in China and the USA.

First, we have identified whether these models are explanatory for the interaction of profitability and possible factors. Despite that the results are not as good as what were expected through F-statistic test, they still can reveal some essential findings. Only model (2) (6) show a relatively proper relationship towards the data, which are significant at the level of $5 \%$ and $10 \%$ respectively. Goodness of fit $\mathrm{R}^{2}$ and adjusted $\mathrm{R}^{2}$ could also amply confirm this considering how volatile exchange rates and macroeconomic transformations during the global financial crisis. Most main variables in model (2) (5) (6) are significant at the level of $10 \%$ via t-test. Additionally, residuals' normality, homoscedasticity and serial correlation have been examined and Figure 7 depicts the results. Model (1)-(5) display the serial correlation except for model (6) so that they have been remedied and new regressions are exhibited. The corrected models generically report better results than the previous.

\subsection{Discussion}

Apparently, these models are not adequately good and appropriate to account for the impacts of exchange rate on profitability in the light of the following factors. Allowing for the simplicity and visibility, it is assumed that their relationship could be linear and all the research is based on it. However, that might be nonlinear but models of nonlinear relation are abstruse to explore due to randomness of some negative data and availability of more accurate indicators. All the analyses, therefore, are still founded on the linear perspective. Although models are not amply cogent and coherent, a variety of interesting findings are able to be observed and explained across literature. 
In terms of similarity, first of all, the adoption of ROE exerts a largely persuasive and influential outcome compared with EPS and ROCE both in China and the USA when profitability is examined exactly as Lee and Suh (2012) did. More importantly, in model (2) (5) (6), the coefficients of EX indicate exchange rate has slight influence on the profitability while GDP and interest rate incorporate more significant and vitally interrelated relationship on performances of MNCs, which can be supported from other researchers. Lee and Suh (2012) believe that profitability disparity varies from different industries; however, Hirschey and Wichern (1984, p. 375) maintain variations "cannot be explained by differences in uncontrolled industry-specific influences". Apart from exchange rate vibration posing subtle impact on MNCs (Harvey, 2005), numerous factors also influence the profitability. Due to the role of environmental factors in the process of internationalization of multinational companies, the success of internationalization can only be achieved by formulating appropriate internationalization strategies according to the national conditions of various countries. The economic environment, political environment and cultural environment in the international environment also have an impact on the operation of enterprises (Sihan, 2018). Despite exchange rates changes existing in the violability of profitability, varied accounting processing methods and standards and risk management measures (Faff, et al., 2005) have been employed by individual companies, which enables to weaken the effects on profitability allowing for the uniformity and consistence of one corporation.

On the other hand, diversity is reflected on China and the USA individually. Although weak-correlation variables will be given priority to formulate models, EX, GDP and IR are selected to embody the relationship. From Figure 9, the correlation of independent variables (EX, GDP and IR) is particularly strong and Chen and Zhang (2007) have identified this while in the USA, the correlation is relatively weak, which is conjectured to be attributed to two primary reasons: different exchange rate regimes and distinctive types of companies. Specifically, China has adopted managed floating currency regime and this relatively pegged exchange rates system contributes to financial industries smooth and sustainable growth along with economic growth. Under the circumstance, MNCs would not enduringly suffer from vulnerability of financial shocks. Nevertheless, free floating exchange rates system in the USA makes the correlation of each variable lower and more volatile. To what extent exchange rates affect the profitability hinges on what kind of regime one economy holds. Cukierman et al. (2004, p. 1206) argue that the optimal regime is given by "the policy maker who can trade off the loss from nominal exchange rate uncertainty against the cost of adopting a given regime" and less flexible regime might lead to more currency attacks. In addition, Top $30 \mathrm{MNCs}$ exhibit totally different types in China and the USA. Over $70 \%$ of MNCs of China are state-owned shareholding corporations while those who in the USA are private ones. Private ones could have more incentives and strategies to develop for the sake of shareholders' benefits. Different types of companies may affect the management, goals, innovativeness, entrepreneurship and how they take advantage of information (Charlebois \& Sapp, 2007) and implement actions to tackle emergencies. Therefore, the rise of net effective exchange rate has different effects on the profits of enterprises of different trade types, different profit margin levels and different types of export products (Guo Ding, 2017).

\section{Conclusion}

This paper has identified whether the changes of exchange rate will influence the MNCs' profitability. From the pervious literature and our results, it is reasonable to conclude that the impact of exchange rate changes on profitability is not significant for Top30 MNCs based on China and the USA. Many multinational companies will hedge foreign exchange rate risk by using various financial instruments. The article also reveals the multinational company profitability varies from the domestic regimes and company individuality. However, the samples containing 30 multinational companies respectively in China and USA from 2007 to 2011 are not sufficiently strong to convince exchange rates influence MNCs profitability and the scope and scale of date should be further to minimize the deviation. Moreover, independent variables chosen for the model can be more subdivided since the collection among them has correlation, which would drift the results' accuracy.

\section{References}

Brealey, R. A., Myers, S. C., and Marcus, A. J. (1999). Fundamentals of corporate finance. Boston: Irwin/McGraw-Hill.

Broda, C. and Romalis, J. (2003). Identifying the relationship between trade and exchange rate volatility. Commodity Prices and Markets, East Asia Seminar on Economics, Volume 20.

Broll, U. and Eckwert, B. (1999). Exchange Rate Volatility and International Trade. Southern Economic Journal, 66, 178-185. 
Charlebois, M. and Sapp, S. (2007). Temporal Patterns in Foreign Exchange Returns and Options. Journal of Money, Credit and Banking, 39(2/3), pp. 443-470.

Chen, Peter F. and Zhang, Guochang. (2007). Segment Profitability, Misvaluation, and Corporate Divestment. The Accounting Review, 82(1), pp. 1-26.

Cukierman, A., Spiegel, Y., and Goldstein, I. (2004). The Choice of Exchange-Rate Regime and Speculative Attacks. Journal of the European Economic Association, 2(6), pp. 1206-1241.

Faff, R. W. and Marshall, Andrew. (2005). International Evidence on the Determinants of Foreign Exchange Rate Exposure of Multinational Corporations. Journal of International Business Studies, 36(5), pp. 539-558.

Gujarati, D. N. and Porter, D. C. (2009). Basic Econometrics. Fifth Edition. McGraw-Hill Higher Education.

Guoding, Wu. (2017). The impact of changes in effective exchange rate on corporate profits [J]. World Economy, 40 (05), pp. 49-72.

Harvey, J. T. (2005). Post Keynesian versus Neoclassical Explanations of Exchange Rate Movements: A Short Look at the Long Run. Journal of Post Keynesian Economics, 28(2), pp. 161-179.

Hirschey, M. and W. Wichern. (1984). Accounting and Market-Value Measures of Profitability: Consistency, Determinants, and Uses. Journal of Business \& Economic Statistics, 2(4), pp. 375-383.

Jinfu Cao. (2020). On the risk management of enterprises under the two-way fluctuation of exchange rate [J]. Financial Circles, (11), pp. 16-17.

Lee, B-S. and Suh, J. (2012). Exchange rate changes and the operating performance of multinationals. European Financial Management, 18, pp. 88-116.

Mundell, Robert A. (1961). A Theory of Optimal Currency Areas. American Economic Review, 51(4), pp. 657-665.

Oskooee, M. B. and Hegerty, S. W. (2009). The effects of exchange-rate volatility on commodity trade between the United States and Mexico. Southern Economic Journal, 75, pp. 1019-1044.

Ross, Westerfield and Jordan. (2008). Fundamentals of Corporate Finance (European Edition). 8th Edition. McGraw-Hill Irwin.

Sung, H. and Lapan, H. E. (2000). Strategic Foreign Direct Investment and Exchange-Rate Uncertainty. International Economic Review, 41(2), pp. 411-423.

Shuo Tian, Dandan Qi. (2019). Research on the impact of RMB exchange rate changes on the profits of export enterprises [J]. World Economic and Political Forum, (05), pp. 43-61.

Sihan, Wang. (2018). The impact of multinational companies' internationalization strategy on their profits-Taking Huawei as an example. Global Market Information Guide, (35), pp. 010-012.

Timothy E. Johnson, Thomas G. Schmitt. (1974). Effectiveness of Earnings per Share Forecasts. Financial Management, 3(2), pp. 64-72.

Xie, Hao and Du, Li. (2007). The impact of exchange rate fluctuations on foreign direct investment. Journal of Zhongnan University Economics and Law, (1), pp. 66-70.

Ye Zhou. (2020). Foreign exchange risk identification and avoidance strategies [J]. Financial Circles, (33), pp. 25-26.

Zhengyan, Zhang. (2018). Analysis of the factors affecting international trade business. Hundred Forum, p. 228. 


\section{Appendix I}

(The model built by Sung and Lapan, 2000 )

A multinational company and a host company produce the same product, but the former's product can be sold in home country and host country while latter only produce and sell the product at host country. The initial exchange between the two countries as $\mathrm{e}_{0}$. TN-Cs cost function are:

$T C_{\mathrm{h}}=F+\mathrm{cq} \quad T C_{\mathrm{f}}=e_{0} F_{f}+e c_{f} q_{f} \mathrm{c}=E(e) c_{f}, \quad F\left\langle\mathrm{e}_{0} F_{f}\right.$

$T C_{\mathrm{h}}$ : cost of domestic production

$F:$ fixed cost of domestic production

$c:$ Variable cost of domestic production per unit of product

$\mathrm{q}$ : Domestic production

$T C_{\mathrm{f}}$ : cost of production at host country

$F_{\mathrm{f}}$ : fixed cost of production at host country

$C_{\mathrm{f}}$ : Variable cost of production per unit of product at host country

$\mathrm{q}_{\mathrm{f}}$ : host country production

Assumed the variable cost is same in two countries, $\mathrm{c}=E(e) c_{f}$ and the fixed cost in home country is lower than foreign country, so $F\left\langle\mathrm{e}_{0} F_{f}\right.$

Demand function at home country: $P=A-B Q$

Cost function of the host company: $C=G+\mathrm{dY}$

Demand function at host country: $P=\mathrm{a}-b Q$

Multinationals and host enterprise decision-making order as follow:

First, firms make decision, multinational firms decide where to produce while host firms decide whether to produce; Second, government macro-control may affect the volatility of the exchange rate; Third, firms make production and marketing decision.

$$
\begin{aligned}
& \prod_{\mathrm{ij}}=\left(A-B Q_{\mathrm{ij}}\right) Q_{i, j}+e\left[a-b\left(Y_{i, j}+y_{i, j}\right)\right] Y_{i, j}-c_{i, j}\left(Q_{i, j}+Y_{i, j}\right) \\
& \pi_{\mathrm{ij}}=\left[\mathrm{a}-b\left(Y_{i, j}+y_{i, j}\right)\right] y_{i, j}-d y_{i, j} \\
& \mathrm{c}_{h, j}=c, c_{f, j}=e c_{f}, c_{b, j}=\min \left(c, e c_{f}\right)
\end{aligned}
$$

If the host firms enter to the market:

$$
\begin{aligned}
& Q_{h, s}=\frac{A-c}{2 B}, Y_{h, s}=\frac{a+d-2(\mathrm{c} / e)}{3 b}, \mathrm{y}_{h, s}=\frac{a+(c / e)-2 d}{3 b} \\
& \prod_{h, s}=\frac{(A-c)^{2}}{4 B}+\frac{e[a+d-2(c / e)]^{2}}{9 b}-F, \pi_{h, s}=\frac{[a+(c / e)-2 d]^{2}}{9 b}-G \\
& Q_{f, s=} \frac{A-e c_{f}}{2 B}, Y_{f, s}=\frac{a+d-2 c_{f}}{3 b}, \mathrm{y}_{f, s}=\frac{a+c_{f}-2 d}{3 b} \\
& \prod_{f, s}=\frac{\left(A-e c_{f}\right)^{2}}{4 B}+\frac{e\left(a+d-2 c_{f}\right)^{2}}{9 b}-e_{0} F_{f}, \pi_{f, s}=\frac{\left(a+\mathrm{c}_{f}-2 d\right)^{2}}{9 b}-G \\
& Q_{b, s}=\frac{A-e c_{m}}{2 B}, Y_{b, s}=\frac{a+d-2 c_{m}}{3 b}, \mathrm{y}_{b, s}=\frac{a+c_{m}-2 d}{3 b} \\
& \mathrm{c}_{m}=\min \left[\left(\frac{c}{e}\right), c_{f}\right]
\end{aligned}
$$




$$
\prod_{b, s}=\frac{\left(A-e c_{m}\right)^{2}}{4 B}+\frac{e\left(a+d-2 c_{m}\right)}{9 b}-F-\mathrm{e}_{0} F_{f}, \pi_{b, s}=\frac{\left(a+c_{m}-2 d\right)^{2}}{9 b}-G
$$

Similarly, if the host firm does not produce, can get:

$$
\begin{aligned}
& Q_{h, n}=\frac{A-c}{2 B}, Y_{h, n}=\frac{a-(c / e)}{2 b}, \prod_{h, n}=\frac{\left(A-e c_{m}\right)^{2}}{4 B}+\frac{e(a-c / e)^{2}}{4 b}-F \\
& Q_{f, n}=\frac{A-e c_{f}}{2 B}, Y_{f, n}=\frac{a-c_{f}}{2 b}, \prod_{f, m}=\frac{\left(A-e c_{f}\right)^{2}}{4 B}+\frac{e\left(a-c_{f}\right)^{2}}{4 b}-e_{0} F_{f} \\
& Q_{b, n}=\frac{A-e c_{m}}{2 B}, Y_{b, n}=\frac{a-c_{m}}{2 b}, \prod_{b, n}=\frac{\left(A-e c_{m}\right)^{2}}{4 B}+\frac{e\left(a-c_{m}\right)^{2}}{4 b}-F-e_{0} F_{f}
\end{aligned}
$$

Assumed that there two companies: one multinational company in its home country and a host country, but the other domestic company producing and selling products in home country. For the multinational firms they have three choices: 1 . produce at home; 2. produce in foreign countries; 3 . produce in both countries. For the domestic firms they can choose whether produce or not. Therefore, it has six different situations.

Assume $\mathrm{i}=h, f, b$ (produce at home, foreign and both), $\mathrm{j}=s, n$ (produce and not produce) representing the choice for multinational and domestic firms. $\prod_{\mathrm{i}, j}$ and $\pi_{\mathrm{ij}}$ represent the profit level of multinational and domestic firms. In order to examine the influence of exchange rate to different company decision, the value functions:

$$
V_{i, j}\left(\sigma_{e}^{2}\right)=E\left[\prod_{\mathrm{i}, j}(e)\right], U_{i, j}\left(\sigma_{e}^{2}\right)=E\left[\pi_{\mathrm{i}, j}(e)\right] \text { have been adopted. }
$$

Exchange rates influencing the different payoff function

\begin{tabular}{|c|c|c|}
\hline Domestic firms & Produce & Not produce \\
\hline Multinational firms & {$\left[V_{h, s}\left(\sigma_{e}^{2}\right), U_{h, s}\left(\sigma_{e}^{2}\right)\right]$} & {$\left[V_{h, n}\left(\sigma_{e}^{2}\right), 0\right]$} \\
\hline produce at home & {$\left[V_{f, s}\left(\sigma_{e}^{2}\right), U_{f, s}\left(\sigma_{e}^{2}\right)\right]$} & {$\left[V_{f, n}\left(\sigma_{e}^{2}\right), 0\right]$} \\
\hline produce at foreign & {$\left[V_{\mathrm{b}, s}\left(\sigma_{e}^{2}\right), U_{b, s}\left(\sigma_{e}^{2}\right)\right]$} & {$\left[V_{b, n}\left(\sigma_{e}^{2}\right), 0\right]$} \\
\hline Produce in both countries & & \\
\hline
\end{tabular}

When the exchange rate does not change, $V_{h, s}(0)>V_{f, s}(0)>V_{b, s}(0), V_{h, n}(0)>V_{f, n}(0)>V_{b, n}(0)$.

Hence, the best strategy for multinational firm is to produce at home; for the host firms, $U_{h, s}(0)=U_{f, s}(0)=U_{b, s}(0)>0$, the best strategy for the host firm is to produce products.

Some explanations about the formula: (1) if multinational firm only produce at home, according to formula (6) and (9), $Q_{h, n}$ and $Q_{h, s}$ are independent with e, therefore the domestic sales would not be affected by exchange rate.(2) If multinational firm produce in both countries, the sale will be higher than the former one. 


\section{Appendix II ROE, EPS and ROCE}

According to the definition from Ross, Westerfield and Jordan (2008, pp. 64-65) and Irala (2005),

1. "Return on equity (ROE) is a measure of how the stockholders fared during the year, ROE is usually measured as follows:

Return on equity=Net Income/Total Equity"

$\mathrm{ROE}=$ earrings after tax/net assets

2. "Earnings per Share (EPS) $=($ Net Income-Dividends on Preferred Stock)/Average Outstanding shares"

3. "Return on capital employed (ROCE) is the ratio of net operating profit to the net operating assets or capital."

The Formula:

Return on capital employed (ROCE)=Earnings before Interest and Tax/(Total Assets-Current Liabilities)

Source:

Irala, Lokanandha Reddy. (2005). EVA: The Right Measure of Managerial Performance? Indian Journal of Accounting \& Finance, 119(2), pp. 1-10.

Ross, Westerfield and Jordan. (2008). Fundamentals of Corporate Finance (European Edition), 8th Edition. McGraw-Hill Irwin.

Comparison of ROE, EPS and ROCE

\begin{tabular}{|c|c|c|}
\hline & Advantage & Disadvantage \\
\hline ROE & $\begin{array}{l}\text { 1. Comparison } \\
\text { ROE connect earnings data and become relevant } \\
\text { measurements that can be compared across sectors. } 2 \text {. } \\
\text { Ease of Calculation } \\
\text { Investors can easily collect the information from a } \\
\text { company's financial statements including balance sheet } \\
\text { and net income. }\end{array}$ & $\begin{array}{l}\text { 1. Subjectivity } \\
\text { As net income is defined as revenues minus expenses, } \\
\text { expenses are subject to many manipulations on the } \\
\text { company's accounting policies like depreciation. } \\
2 \text {. The complementation between two indicators is not } \\
\text { strong. } \\
\text { Asset size of listed companies are not equal, it should } \\
\text { not assess its effectiveness and management degree by } \\
\text { the enterprise income indicators on absolute value. }\end{array}$ \\
\hline ROCE & $\begin{array}{l}\text { 3. Comparison } \\
\text { ROCE can be used to compare performance with other } \\
\text { divisions and companies. Also it is fair to divisions with } \\
\text { different sizes of investment }\end{array}$ & $\begin{array}{l}\text { 1. Ignores the time value of money } \\
\text { ROCE does not take the time value of money into } \\
\text { account. } \\
\text { 2. No general agreement about how capital employed } \\
\text { should be calculated. Therefore, the method permit the } \\
\text { decision maker to choose a definition of ROCE that } \\
\text { suits their preconception of a project's desirability most. }\end{array}$ \\
\hline EPS & $\begin{array}{l}\text { 1. Ease of Calculation } \\
\text { Investors can easily collect the information from a } \\
\text { company's financial statements including balance sheet } \\
\text { and net income. } \\
2 \text {. Avoid the subjective factors } \\
\text { EPS can reflect the company's profitability and } \\
\text { investment risk objectively without the influence of } \\
\text { behavioral factors like risk averse and confidence. }\end{array}$ & $\begin{array}{l}\text { Ignores the time value of money } \\
\text { EPS does not take the time value of money into } \\
\text { account, which might lead to one-sided pursuit of profit } \\
\text { maximization and a variety of short-term behavior of } \\
\text { enterprises }\end{array}$ \\
\hline
\end{tabular}




\section{Appendix III Figures in Empirical Results}

Figure 1

Dependent Variable: EPS

Method: Least Squares

Date: 03/02/13 Time: 22:29

Sample: 1150

Included observations: 150

\begin{tabular}{ccccc}
\hline \hline Variable & Coefficient & Std. Error & t-Statistic & Prob. \\
\hline \hline C & -1.447084 & 8.278382 & -0.174803 & 0.8615 \\
EX & 0.349014 & 1.110301 & 0.314342 & 0.7537 \\
GDP & 6.924667 & 48.45186 & 0.142918 & 0.8866 \\
IR & 15.35086 & 58.01070 & 0.264621 & 0.7917 \\
\hline \hline R-squared & 0.001321 & Mean dependent var & 1.479641 \\
Adjusted R-squared & -0.019200 & S.D. dependent var & 3.162869 \\
S.E. of regression & 3.193088 & Akaike info criterion & 5.186159 \\
Sum squared resid & 1488.589 & Schwarz criterion & 5.266442 \\
Log likelihood & -384.9619 & Hannan-Quinn criter. & 5.218776 \\
F-statistic & 0.064375 & Durbin-Watson stat & 0.459810 \\
Prob (F-statistic) & 0.978607 & & \\
\hline \hline
\end{tabular}

Breusch-Godfrey Serial Correlation LM Test:

\begin{tabular}{cccc}
\hline \hline F-statistic & 211.4599 & Prob. F(1,145) & 0.0000 \\
Obs*R-squared & 88.98332 & Prob. Chi-Square(1) & 0.0000 \\
\hline \hline
\end{tabular}

Test Equation:

Dependent Variable: RESID

Method: Least Squares

Date: 03/03/13 Time: 10:55

Sample: 1150

Included observations: 150

Presample missing value lagged residuals set to zero.

\begin{tabular}{ccccc}
\hline \hline Variable & Coefficient & Std. Error & t-Statistic & Prob. \\
\hline \hline C & 2.063322 & 5.299956 & 0.389309 & 0.6976 \\
EX & -0.243309 & 0.710775 & -0.342314 & 0.7326 \\
GDP & -6.189709 & 31.01148 & -0.199594 & 0.8421 \\
IR & -8.697480 & 37.13091 & -0.234238 & 0.8151 \\
RESID(-1) & 0.770663 & 0.052997 & 14.54166 & 0.0000 \\
\hline \hline R-squared & 0.593222 & Mean dependent var & $1.49 \mathrm{E}-15$ \\
Adjusted R-squared & 0.582001 & S.D. dependent var & 3.160780 \\
S.E. of regression & 2.043535 & Akaike info criterion & 4.300004 \\
Sum squared resid & 605.5249 & Schwarz criterion & 4.400359 \\
Log likelihood & -317.5003 & Hannan-Quinn criter. & 4.340775 \\
F-statistic & 52.86498 & Durbin-Watson stat & 1.852524 \\
Prob(F-statistic) & 0.000000 & & \\
\hline \hline
\end{tabular}


Heteroskedasticity Test: Breusch-Pagan-Godfrey

\begin{tabular}{cccc}
\hline \hline F-statistic & 0.149306 & Prob. F(3,146) & 0.9300 \\
Obs*R-squared & 0.458781 & Prob. Chi-Square(3) & 0.9278 \\
Scaled explained SS & 4.763261 & Prob. Chi-Square(3) & 0.1900 \\
\hline \hline
\end{tabular}

Test Equation:

Dependent Variable: RESID ${ }^{\wedge} 2$

Method: Least Squares

Date: 03/03/13 Time: 10:59

Sample: 1150

Included observations: 150

\begin{tabular}{ccccc}
\hline \hline Variable & Coefficient & Std. Error & t-Statistic & Prob. \\
\hline \hline C & -8.722990 & 121.9059 & -0.071555 & 0.9431 \\
EX & 2.694736 & 16.35009 & 0.164815 & 0.8693 \\
GDP & -116.8211 & 713.4932 & -0.163731 & 0.8702 \\
IR & 345.1715 & 854.2550 & 0.404061 & 0.6868 \\
\hline \hline R-squared & 0.003059 & Mean dependent var & 9.923924 \\
Adjusted R-squared & -0.017427 & S.D. dependent var & 46.61640 \\
S.E. of regression & 47.02083 & Akaike info criterion & 10.56536 \\
Sum squared resid & 322799.9 & Schwarz criterion & 10.64565 \\
Log likelihood & -788.4022 & Hannan-Quinn criter. & 10.59798 \\
F-statistic & 0.149306 & Durbin-Watson stat & 0.515479 \\
Prob (F-statistic) & 0.929996 & & \\
\hline \hline
\end{tabular}

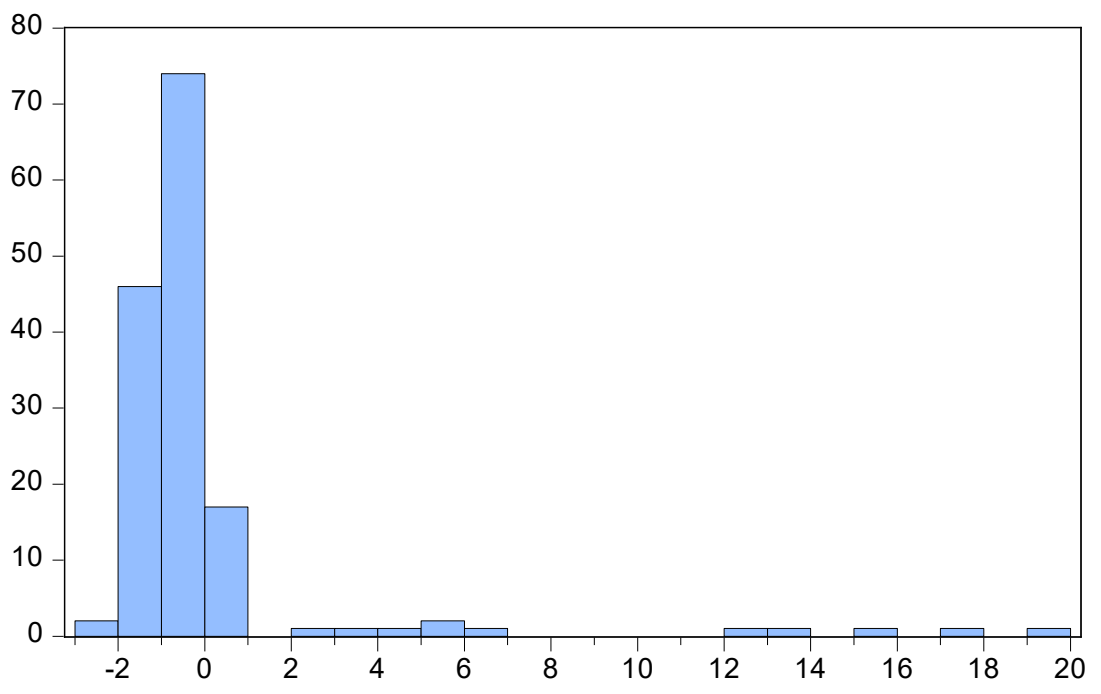

\begin{tabular}{|c|c|}
\hline \multicolumn{2}{|c|}{$\begin{array}{l}\text { Series: Residuals } \\
\text { Sample } 1150 \\
\text { Observations } 150\end{array}$} \\
\hline Mean & $1.49 \mathrm{e}-15$ \\
\hline Median & -0.785575 \\
\hline Maximum & 19.08108 \\
\hline Minimum & -2.658919 \\
\hline Std. Dev. & 3.160780 \\
\hline Skewness & 4.408085 \\
\hline Kurtosis & 22.91824 \\
\hline Jarque-Bera & 2965.382 \\
\hline Probability & 0.000000 \\
\hline
\end{tabular}


Figure 2

Dependent Variable: ROE

Method: Least Squares

Date: 03/02/13 Time: 22:30

Sample: 1150

Included observations: 150

\begin{tabular}{ccccc}
\hline \hline Variable & Coefficient & Std. Error & t-Statistic & Prob. \\
\hline \hline C & -0.180238 & 0.266658 & -0.675916 & 0.5002 \\
EX & 0.027486 & 0.035764 & 0.768530 & 0.4434 \\
GDP & 2.014311 & 1.560699 & 1.290646 & 0.1989 \\
IR & 0.534833 & 1.868602 & 0.286221 & 0.7751 \\
\hline \hline R-squared & 0.053201 & Mean dependent var & 0.163063 \\
Adjusted R-squared & 0.033746 & S.D. dependent var & 0.104634 \\
S.E. of regression & 0.102854 & Akaike info criterion & -1.684715 \\
Sum squared resid & 1.544516 & Schwarz criterion & -1.604431 \\
Log likelihood & 130.3536 & Hannan-Quinn criter. & -1.652098 \\
F-statistic & 2.734610 & Durbin-Watson stat & 1.018293 \\
Prob(F-statistic) & 0.045831 & & \\
\hline \hline
\end{tabular}

Breusch-Godfrey Serial Correlation LM Test:

\begin{tabular}{cccc}
\hline \hline F-statistic & 31.77991 & Prob. F(1,145) & 0.0000 \\
Obs*R-squared & 26.96565 & Prob. Chi-Square(1) & 0.0000 \\
\hline \hline
\end{tabular}

Test Equation:

Dependent Variable: RESID

Method: Least Squares

Date: 03/06/13 Time: 03:08

Sample: 1150

Included observations: 150

Presample missing value lagged residuals set to zero.

\begin{tabular}{ccccc}
\hline \hline Variable & Coefficient & Std. Error & t-Statistic & Prob. \\
\hline \hline C & 0.029704 & 0.242391 & 0.122546 & 0.9026 \\
EX & -0.003623 & 0.032508 & -0.111436 & 0.9114 \\
GDP & -0.087145 & 1.418421 & -0.061438 & 0.9511 \\
IR & -0.120288 & 1.698287 & -0.070829 & 0.9436 \\
RESID(-1) & 0.424384 & 0.075281 & 5.637367 & 0.0000 \\
\hline \hline R-squared & 0.179771 & Mean dependent var & $1.91 \mathrm{E}-16$ \\
Adjusted R-squared & 0.157144 & S.D. dependent var & 0.101813 \\
S.E. of regression & 0.093472 & Akaike info criterion & -1.869553 \\
Sum squared resid & 1.266856 & Schwarz criterion & -1.769199 \\
Log likelihood & 145.2165 & Hannan-Quinn criter. & -1.828782 \\
F-statistic & 7.944976 & Durbin-Watson stat & 1.905940 \\
Prob(F-statistic) & 0.000008 & & \\
\hline \hline
\end{tabular}


Heteroskedasticity Test: Breusch-Pagan-Godfrey

\begin{tabular}{cccc}
\hline \hline F-statistic & 0.739710 & Prob. F(3,146) & 0.5300 \\
Obs*R-squared & 2.245792 & Prob. Chi-Square(3) & 0.5230 \\
Scaled explained SS & 5.481459 & Prob. Chi-Square(3) & 0.1398 \\
\hline \hline
\end{tabular}

Test Equation:

Dependent Variable: RESID ${ }^{\wedge} 2$

Method: Least Squares

Date: 03/06/13 Time: 03:09

Sample: 1150

Included observations: 150

\begin{tabular}{ccccc}
\hline \hline Variable & Coefficient & Std. Error & t-Statistic & Prob. \\
\hline \hline C & -0.006712 & 0.060960 & -0.110110 & 0.9125 \\
EX & -0.000812 & 0.008176 & -0.099303 & 0.9210 \\
GDP & -0.083496 & 0.356788 & -0.234021 & 0.8153 \\
IR & 0.466943 & 0.427178 & 1.093089 & 0.2762 \\
\hline \hline R-squared & 0.014972 & Mean dependent var & 0.010297 \\
Adjusted R-squared & -0.005268 & S.D. dependent var & 0.023451 \\
S.E. of regression & 0.023513 & Akaike info criterion & -4.636207 \\
Sum squared resid & 0.080719 & Schwarz criterion & -4.555924 \\
Log likelihood & 351.7156 & Hannan-Quinn criter. & -4.603591 \\
F-statistic & 0.739710 & Durbin-Watson stat & 1.234049 \\
Prob(F-statistic) & 0.529992 & & \\
\hline \hline
\end{tabular}

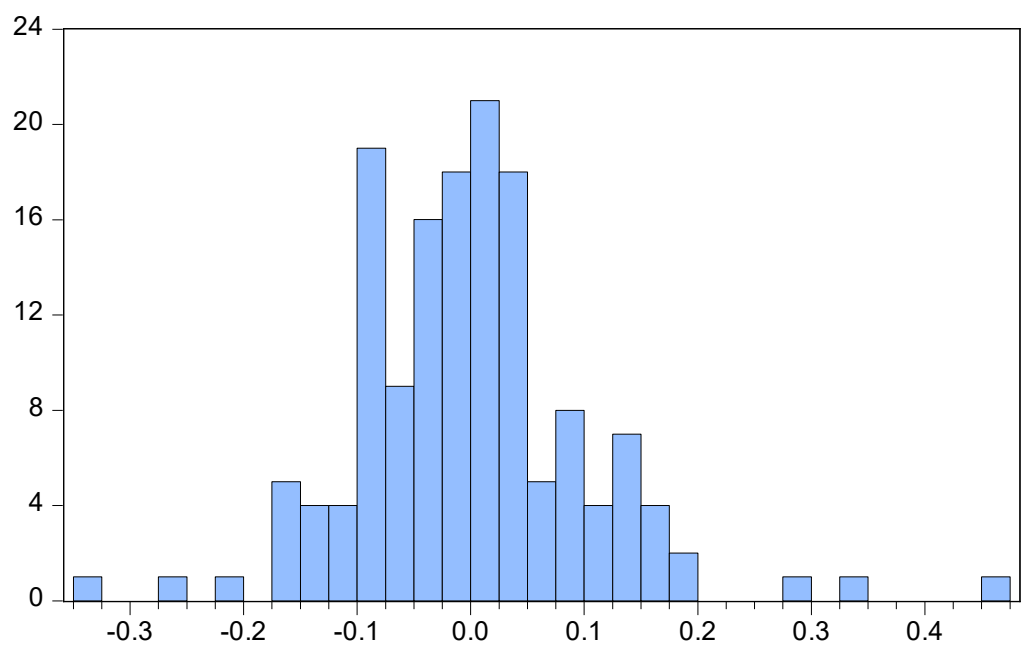

\begin{tabular}{|lr|}
\hline \multicolumn{2}{l}{ Series: Residuals } \\
Sample 1150 \\
Observations 150 \\
Mean & $1.91 \mathrm{e}-16$ \\
Median & -0.003693 \\
Maximum & 0.453722 \\
Minimum & -0.329895 \\
Std. Dev. & 0.101813 \\
Skewness & 0.706387 \\
Kurtosis & 6.152682 \\
& \\
Jarque-Bera & 74.59584 \\
Probability & 0.000000 \\
\hline
\end{tabular}


Figure 3

Dependent Variable: ROCE

Method: Least Squares

Date: 03/02/13 Time: 22:31

Sample: 1150

Included observations: 145

\begin{tabular}{ccccc}
\hline \hline Variable & Coefficient & Std. Error & t-Statistic & Prob. \\
\hline \hline C & 0.040238 & 0.345381 & 0.116503 & 0.9074 \\
EX & -0.014160 & 0.046128 & -0.306985 & 0.7593 \\
GDP & 0.340643 & 1.999032 & 0.170404 & 0.8649 \\
IR & 1.484631 & 2.377817 & 0.624367 & 0.5334 \\
\hline \hline R-squared & 0.040074 & Mean dependent var & 0.115940 \\
Adjusted R-squared & 0.019650 & S.D. dependent var & 0.131593 \\
S.E. of regression & 0.130294 & Akaike info criterion & -1.210853 \\
Sum squared resid & 2.393678 & Schwarz criterion & -1.128736 \\
Log likelihood & 91.78685 & Hannan-Quinn criter. & -1.177486 \\
F-statistic & 2.662092 & Durbin-Watson stat & 1.152913 \\
Prob(F-statistic) & 0.092443 & & \\
\hline \hline
\end{tabular}

Breusch-Godfrey Serial Correlation LM Test:

\begin{tabular}{cccc}
\hline \hline F-statistic & 31.85909 & Prob. F $(1,140)$ & 0.0000 \\
Obs*R-squared & 26.87998 & Prob. Chi-Square(1) & 0.0000 \\
\hline \hline
\end{tabular}

Test Equation:

Dependent Variable: RESID

Method: Least Squares

Date: 03/06/13 Time: 03:11

Sample: 1150

Included observations: 145

Presample and interior missing value lagged residuals set to zero.

\begin{tabular}{ccccc}
\hline \hline Variable & Coefficient & Std. Error & t-Statistic & Prob. \\
\hline \hline C & -0.018082 & 0.312856 & -0.057796 & 0.9540 \\
EX & 0.002833 & 0.041784 & 0.067811 & 0.9460 \\
GDP & 0.044318 & 1.810703 & 0.024476 & 0.9805 \\
IR & 0.044266 & 2.153796 & 0.020553 & 0.9836 \\
RESID(-1) & 0.433696 & 0.076837 & 5.644386 & 0.0000 \\
\hline \hline R-squared & 0.185379 & Mean dependent var & $-2.02 \mathrm{E}-17$ \\
Adjusted R-squared & 0.162104 & S.D. dependent var & 0.128929 \\
S.E. of regression & 0.118018 & Akaike info criterion & -1.402092 \\
Sum squared resid & 1.949940 & Schwarz criterion & -1.299447 \\
Log likelihood & 106.6517 & Hannan-Quinn criter. & -1.360384 \\
F-statistic & 7.964773 & Durbin-Watson stat & 2.052174 \\
Prob(F-statistic) & 0.000008 & & \\
\hline \hline
\end{tabular}


Heteroskedasticity Test: Breusch-Pagan-Godfrey

\begin{tabular}{cccc}
\hline \hline F-statistic & 0.977427 & Prob. F(3,141) & 0.4053 \\
Obs*R-squared & 2.954032 & Prob. Chi-Square(3) & 0.3988 \\
Scaled explained SS & 30.68054 & Prob. Chi-Square(3) & 0.0000 \\
\hline \hline
\end{tabular}

Test Equation:

Dependent Variable: RESID^2

Method: Least Squares

Date: 03/06/13 Time: 03:11

Sample: 1150

Included observations: 145

\begin{tabular}{ccccc}
\hline \hline Variable & Coefficient & Std. Error & t-Statistic & Prob. \\
\hline \hline C & -0.287078 & 0.205857 & -1.394548 & 0.1653 \\
EX & 0.044129 & 0.027493 & 1.605069 & 0.1107 \\
GDP & 1.994682 & 1.191480 & 1.674121 & 0.0963 \\
IR & -1.055613 & 1.417247 & -0.744833 & 0.4576 \\
\hline \hline R-squared & 0.020373 & Mean dependent var & 0.016508 \\
Adjusted R-squared & -0.000471 & S.D. dependent var & 0.077640 \\
S.E. of regression & 0.077659 & Akaike info criterion & -2.245786 \\
Sum squared resid & 0.850354 & Schwarz criterion & -2.163670 \\
Log likelihood & 166.8195 & Hannan-Quinn criter. & -2.212420 \\
F-statistic & 0.977427 & Durbin-Watson stat & 1.948203 \\
Prob(F-statistic) & 0.405322 & & \\
\hline \hline
\end{tabular}

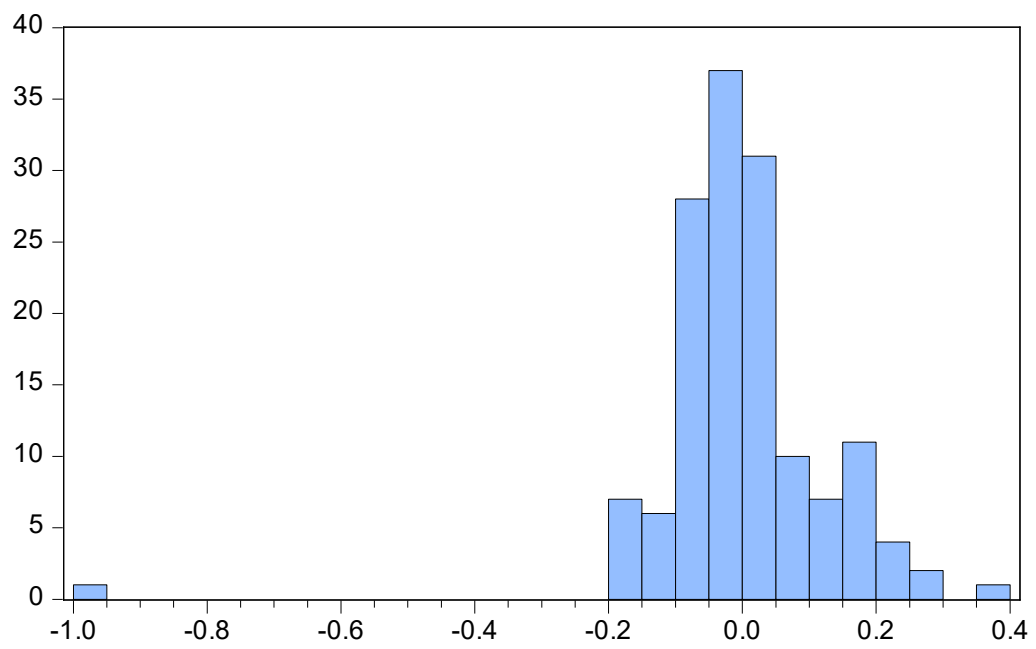

Series: Residuals

Sample 1150

Observations 145

Mean

$-2.02 \mathrm{e}-17$

Median $-0.007166$

Maximum

0.396779

Minimum

$-0.957444$

Std. Dev.

0.128929

Skewness

$-2.297355$

Kurtosis

22.96724

Jarque-Bera 2536.305

Probability 
Figure 4

Dependent Variable: EPS

Method: Least Squares

Date: 03/02/13 Time: 22:44

Sample: 1150

Included observations: 150

\begin{tabular}{ccccc}
\hline \hline Variable & Coefficient & Std. Error & t-Statistic & Prob. \\
\hline \hline C & 1534.487 & 995.3952 & 1.541586 & 0.1253 \\
EX & -1422.075 & 1021.426 & -1.392245 & 0.1660 \\
GDP & -1882.373 & 2676.332 & -0.703340 & 0.4830 \\
IR & 369.2418 & 3374.216 & 0.109430 & 0.9130 \\
\hline \hline R-squared & 0.018741 & Mean dependent var & 53.20236 \\
Adjusted R-squared & -0.001422 & S.D. dependent var & 432.9421 \\
S.E. of regression & 433.2497 & Akaike info criterion & 15.00681 \\
Sum squared resid & 27404979 & Schwarz criterion & 15.08709 \\
Log likelihood & -1121.511 & Hannan-Quinn criter. & 15.03943 \\
F-statistic & 0.929488 & Durbin-Watson stat & 1.005843 \\
Prob(F-statistic) & 0.428199 & & \\
\hline \hline
\end{tabular}

Breusch-Godfrey Serial Correlation LM Test:

\begin{tabular}{cccc}
\hline \hline F-statistic & 47.66716 & Prob. F $(1,145)$ & 0.0000 \\
Obs*R-squared & 37.11101 & Prob. Chi-Square(1) & 0.0000 \\
\hline \hline
\end{tabular}

Test Equation:

Dependent Variable: RESID

Method: Least Squares

Date: 03/06/13 Time: 03:13

Sample: 1150

Included observations: 150

Presample missing value lagged residuals set to zero.

\begin{tabular}{ccccc}
\hline \hline Variable & Coefficient & Std. Error & t-Statistic & Prob. \\
\hline \hline C & -171.0211 & 866.8531 & -0.197290 & 0.8439 \\
EX & 188.7381 & 889.5789 & 0.212166 & 0.8323 \\
GDP & 280.0137 & 2330.120 & 0.120171 & 0.9045 \\
IR & -671.5595 & 2938.891 & -0.228508 & 0.8196 \\
RESID(-1) & 0.497922 & 0.072119 & 6.904141 & 0.0000 \\
\hline \hline R-squared & 0.247407 & Mean dependent var & $-6.67 \mathrm{E}-13$ \\
Adjusted R-squared & 0.226646 & S.D. dependent var & 428.8660 \\
S.E. of regression & 377.1472 & Akaike info criterion & 14.73591 \\
Sum squared resid & 20624802 & Schwarz criterion & 14.83627 \\
Log likelihood & -1100.193 & Hannan-Quinn criter. & 14.77668 \\
F-statistic & 11.91679 & Durbin-Watson stat & 1.675275 \\
Prob(F-statistic) & 0.000000 & & \\
\hline \hline
\end{tabular}


Heteroskedasticity Test: Breusch-Pagan-Godfrey

\begin{tabular}{cccc}
\hline \hline F-statistic & 1.001990 & Prob. F(3,146) & 0.3939 \\
Obs*R-squared & 3.026023 & Prob. Chi-Square(3) & 0.3876 \\
Scaled explained SS & 99.29054 & Prob. Chi-Square(3) & 0.0000 \\
\hline \hline
\end{tabular}

Test Equation:

Dependent Variable: RESID^2

Method: Least Squares

Date: 03/06/13 Time: 03:13

Sample: 1150

Included observations: 150

\begin{tabular}{ccccc}
\hline \hline Variable & Coefficient & Std. Error & t-Statistic & Prob. \\
\hline \hline C & 5691312. & 3505181. & 1.623686 & 0.1066 \\
EX & -5316786. & 3596844. & -1.478181 & 0.1415 \\
GDP & -7253294. & 9424426. & -0.769627 & 0.4428 \\
IR & 2064830. & 11881953 & 0.173779 & 0.8623 \\
\hline \hline R-squared & 0.020173 & Mean dependent var & 182699.9 \\
Adjusted R-squared & 0.000040 & S.D. dependent var & 1525675. \\
S.E. of regression & 1525644. & Akaike info criterion & 31.34004 \\
Sum squared resid & $3.40 \mathrm{E}+14$ & Schwarz criterion & 31.42032 \\
Log likelihood & -2346.503 & Hannan-Quinn criter. & 31.37265 \\
F-statistic & 1.001990 & Durbin-Watson stat & 1.007141 \\
Prob(F-statistic) & 0.393853 & & \\
\hline \hline
\end{tabular}

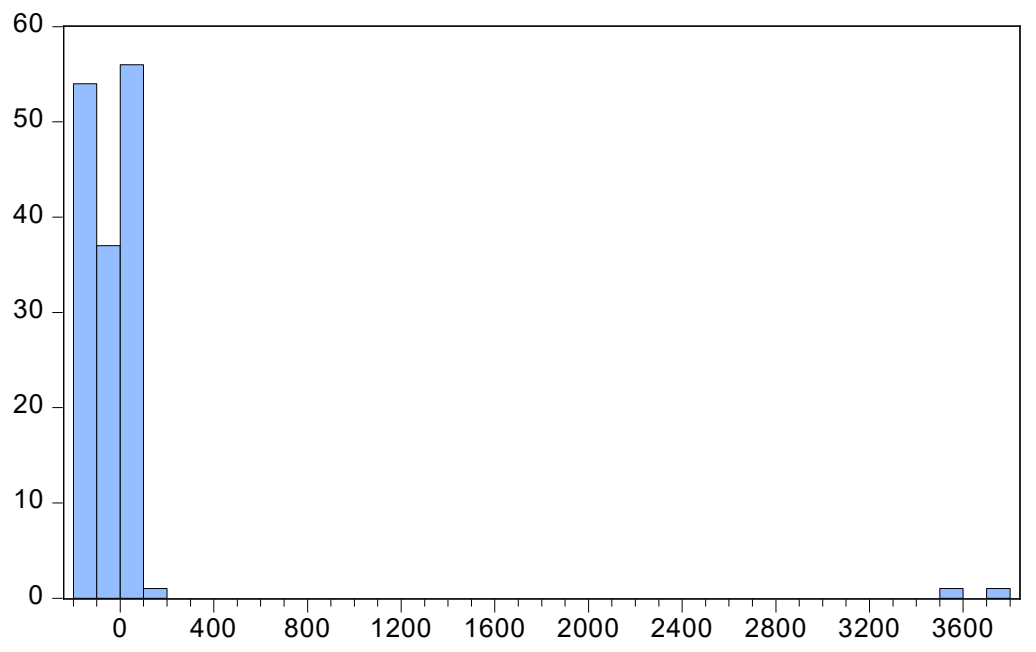

Series: Residuals Sample 1150

Observations 150

Mean

$-6.67 e-13$

Median $-30.01671$

Maximum

3727.778

Minimum

$-142.0318$

Std. Dev.

428.8660

Skewness

Kurtosis

8.231155

Jarque-Bera

29976.26

Probability 
Figure 5

Dependent Variable: ROE

Method: Least Squares

Date: 03/02/13 Time: 22:46

Sample: 1150

Included observations: 150

\begin{tabular}{ccccc}
\hline \hline Variable & Coefficient & Std. Error & t-Statistic & Prob. \\
\hline \hline C & 0.751987 & 1.718863 & 0.437491 & 0.6624 \\
EX & -0.348670 & 1.763813 & -0.197680 & 0.8436 \\
GDP & -0.312168 & 4.621530 & -0.067546 & 0.9462 \\
IR & -2.370229 & 5.826647 & -0.406791 & 0.6848 \\
\hline \hline R-squared & 0.003967 & Mean dependent var & 0.286161 \\
Adjusted R-squared & -0.016499 & S.D. dependent var & 0.742046 \\
S.E. of regression & 0.748142 & Akaike info criterion & 2.283857 \\
Sum squared resid & 81.71861 & Schwarz criterion & 2.364140 \\
Log likelihood & -167.2893 & Hannan-Quinn criter. & 2.316474 \\
F-statistic & 0.193843 & Durbin-Watson stat & 0.562240 \\
Prob(F-statistic) & 0.900460 & & \\
\hline \hline
\end{tabular}

Breusch-Godfrey Serial Correlation LM Test:

\begin{tabular}{cccc}
\hline \hline F-statistic & 155.1711 & Prob. F $(1,145)$ & 0.0000 \\
Obs*R-squared & 77.54132 & Prob. Chi-Square(1) & 0.0000 \\
\hline \hline
\end{tabular}

Test Equation:

Dependent Variable: RESID

Method: Least Squares

Date: 03/06/13 Time: 03:15

Sample: 1150

Included observations: 150

Presample missing value lagged residuals set to zero.

\begin{tabular}{ccccc}
\hline \hline Variable & Coefficient & Std. Error & t-Statistic & Prob. \\
\hline \hline C & 0.238528 & 1.198916 & 0.198953 & 0.8426 \\
EX & -0.257823 & 1.230286 & -0.209563 & 0.8343 \\
GDP & -0.378689 & 3.223273 & -0.117486 & 0.9066 \\
IR & 0.770665 & 4.064068 & 0.189629 & 0.8499 \\
RESID(-1) & 0.719228 & 0.057738 & 12.45677 & 0.0000 \\
\hline \hline R-squared & 0.516942 & Mean dependent var & $-1.95 \mathrm{E}-16$ \\
Adjusted R-squared & 0.503616 & S.D. dependent var & 0.740572 \\
S.E. of regression & 0.521766 & Akaike info criterion & 1.569571 \\
Sum squared resid & 39.47482 & Schwarz criterion & 1.669926 \\
Log likelihood & -112.7179 & Hannan-Quinn criter. & 1.610342 \\
F-statistic & 38.79277 & Durbin-Watson stat & 1.646465 \\
Prob(F-statistic) & 0.000000 & & \\
\hline \hline
\end{tabular}


Heteroskedasticity Test: Breusch-Pagan-Godfrey

\begin{tabular}{llll}
\hline \hline F-statistic & 0.456252 & Prob. F(3,146) & 0.7133 \\
Obs*R-squared & 1.393195 & Prob. Chi-Square(3) & 0.7071 \\
Scaled explained SS & 20.52971 & Prob. Chi-Square(3) & 0.0001 \\
\hline \hline
\end{tabular}

Test Equation:

Dependent Variable: RESID^2

Method: Least Squares

Date: 03/06/13 Time: 03:15

Sample: 1150

Included observations: 150

\begin{tabular}{lllll}
\hline \hline Variable & Coefficient & Std. Error & t-Statistic & Prob. \\
\hline \hline C & 3.688050 & 7.043179 & 0.523634 & 0.6013 \\
EX & -2.879531 & 7.227363 & -0.398421 & 0.6909 \\
GDP & -12.21924 & 18.93709 & -0.645254 & 0.5198 \\
IR & -3.900847 & 23.87515 & -0.163385 & 0.8704 \\
\hline \hline R-squared & 0.009288 & Mean dependent var & 0.544791 \\
Adjusted R-squared & -0.011069 & S.D. dependent var & 3.048745 \\
S.E. of regression & 3.065572 & Akaike info criterion & 5.104650 \\
Sum squared resid & 1372.068 & Schwarz criterion & 5.184933 \\
Log likelihood & -378.8487 & Hannan-Quinn criter. & 5.137267 \\
F-statistic & 0.456252 & Durbin-Watson stat & 0.469296 \\
Prob(F-statistic) & 0.713281 & & & \\
\hline \hline
\end{tabular}

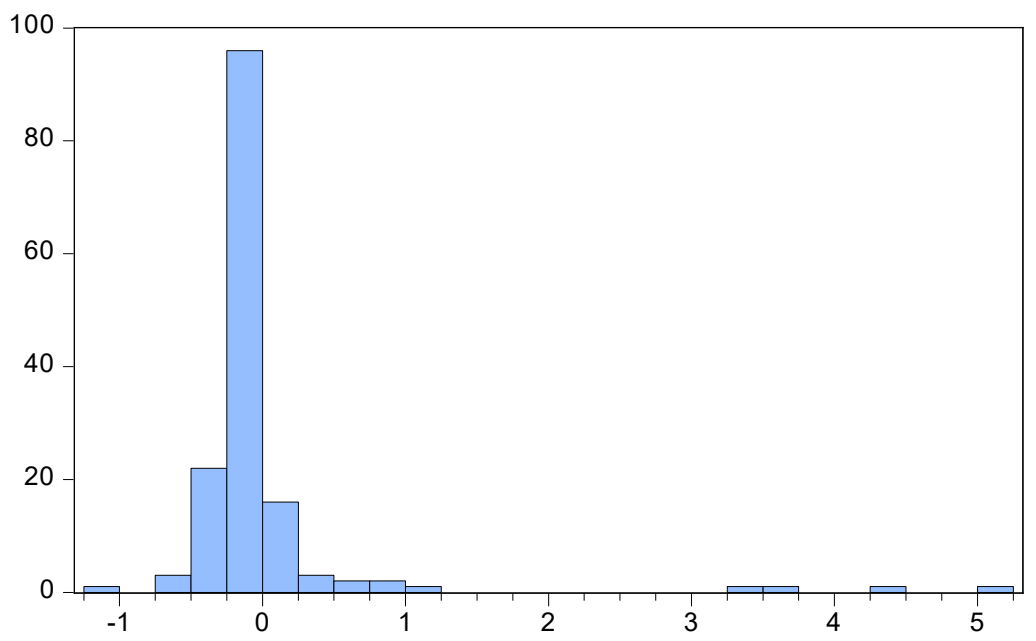

\begin{tabular}{|c|c|}
\hline \multicolumn{2}{|c|}{$\begin{array}{l}\text { Series: Residuals } \\
\text { Sample } 1150 \\
\text { Observations } 150\end{array}$} \\
\hline Mean & $-1.95 e-16$ \\
\hline Median & -0.147480 \\
\hline Maximum & 5.244140 \\
\hline Minimum & -1.162202 \\
\hline Std. Dev. & 0.740572 \\
\hline Skewness & 5.184007 \\
\hline Kurtosis & 32.10840 \\
\hline Jarque-Bera & 5967.467 \\
\hline Probability & 0.000000 \\
\hline
\end{tabular}


Figure 6

Dependent Variable: ROCE

Method: Least Squares

Date: 03/02/13 Time: 22:46

Sample: 1150

Included observations: 140

\begin{tabular}{ccccc}
\hline \hline Variable & Coefficient & Std. Error & t-Statistic & Prob. \\
\hline \hline C & -24.89453 & 19.63415 & -1.267920 & 0.2070 \\
EX & 25.89292 & 20.14760 & 1.285161 & 0.2009 \\
GDP & 6.618251 & 52.79061 & 0.125368 & 0.9004 \\
IR & -37.40394 & 66.55637 & -0.561989 & 0.5750 \\
\hline \hline R-squared & 0.022462 & Mean dependent var & 0.966815 \\
Adjusted R-squared & 0.000899 & S.D. dependent var & 8.259784 \\
S.E. of regression & 8.256070 & Akaike info criterion & 7.087930 \\
Sum squared resid & 9270.126 & Schwarz criterion & 7.171977 \\
Log likelihood & -492.1551 & Hannan-Quinn criter. & 7.122084 \\
F-statistic & 2.741693 & Durbin-Watson stat & 1.958494 \\
Prob(F-statistic) & 0.090311 & & \\
\hline \hline
\end{tabular}

Heteroskedasticity Test: Breusch-Pagan-Godfrey

\begin{tabular}{cccc}
\hline \hline F-statistic & 1.136034 & Prob. F(3,136) & 0.3369 \\
Obs*R-squared & 3.422573 & Prob. Chi-Square(3) & 0.3309 \\
Scaled explained SS & 209.7793 & Prob. Chi-Square(3) & 0.0000 \\
\hline \hline
\end{tabular}

Test Equation:

Dependent Variable: RESID ${ }^{\wedge} 2$

Method: Least Squares

Date: 03/06/13 Time: 03:17

Sample: 1150

Included observations: 140

\begin{tabular}{ccccc}
\hline \hline Variable & Coefficient & Std. Error & t-Statistic & Prob. \\
\hline \hline C & -2289.870 & 1798.562 & -1.273167 & 0.2051 \\
EX & 2367.333 & 1845.596 & 1.282693 & 0.2018 \\
GDP & 343.4852 & 4835.818 & 0.071029 & 0.9435 \\
IR & -3658.356 & 6096.813 & -0.600044 & 0.5495 \\
\hline \hline R-squared & 0.024447 & Mean dependent var & 66.21519 \\
Adjusted R-squared & 0.002927 & S.D. dependent var & 757.3965 \\
S.E. of regression & 756.2870 & Akaike info criterion & 16.12287 \\
Sum squared resid & 77787933 & Schwarz criterion & 16.20692 \\
Log likelihood & -1124.601 & Hannan-Quinn criter. & 16.15703 \\
F-statistic & 1.136034 & Durbin-Watson stat & 2.019739 \\
Prob(F-statistic) & 0.336877 & & \\
\hline \hline
\end{tabular}




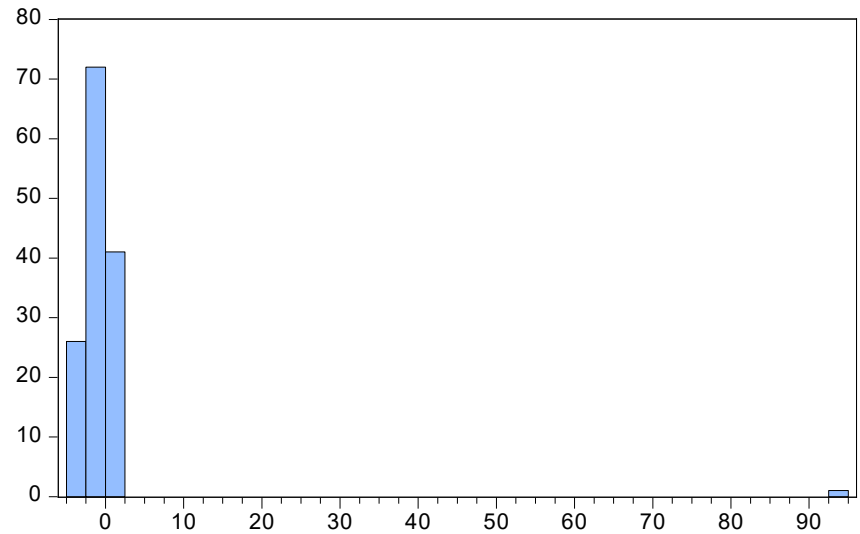

\begin{tabular}{|c|c|}
\hline \multicolumn{2}{|c|}{$\begin{array}{l}\text { Series: Residuals } \\
\text { Sample } 1150 \\
\text { Observations } 140\end{array}$} \\
\hline Mean & $7.39 \mathrm{e}-15$ \\
\hline Median & -0.216244 \\
\hline Maximum & 94.67705 \\
\hline Minimum & -3.454564 \\
\hline Std. Dev. & 8.166490 \\
\hline Skewness & 11.24032 \\
\hline Kurtosis & 130.9027 \\
\hline Jarque-Bera & 98376.09 \\
\hline Probability & 0.000000 \\
\hline
\end{tabular}

Figure 7

\begin{tabular}{|c|c|c|c|}
\hline Models & Autocorrelated & Heteroskedasticity & Normally distributed \\
\hline$(1)$ & + & - & - \\
\hline$(2)$ & + & - & - \\
\hline$(3)$ & + & - & - \\
\hline$(4)$ & + & - & - \\
\hline$(5)$ & + & - & - \\
\hline$(6)$ & - & - & - \\
\hline
\end{tabular}

Note: “+”means yes; “-”means no.

Figure 8

\begin{tabular}{|c|c|c|c|c|c|c|}
\hline Model & C & EX & GDP & IR & $\mathrm{R}^{2}$ & Adjusted R $^{2}$ \\
\hline$(1)$ & -1.447 & 0.349 & 6.925 & 15.351 & 0.0013 & -0.0192 \\
\hline$(2)$ & -0.180 & 0.027 & 2.014 & 0.535 & 0.0532 & 0.0337 \\
\hline$(3)$ & 0.040 & -0.014 & 0.341 & 1.485 & 0.0401 & 0.0197 \\
\hline$(4)$ & 1534.487 & -1422.075 & -1882.373 & 369.242 & 0.0187 & -0.0014 \\
\hline$(5)$ & 0.752 & -0.349 & -0.312 & -2.370 & 0.0040 & -0.0165 \\
\hline$(6)$ & -24.895 & 25.895 & 6.619 & -37.404 & 0.0225 & 0.0009 \\
\hline
\end{tabular}

Figure 9

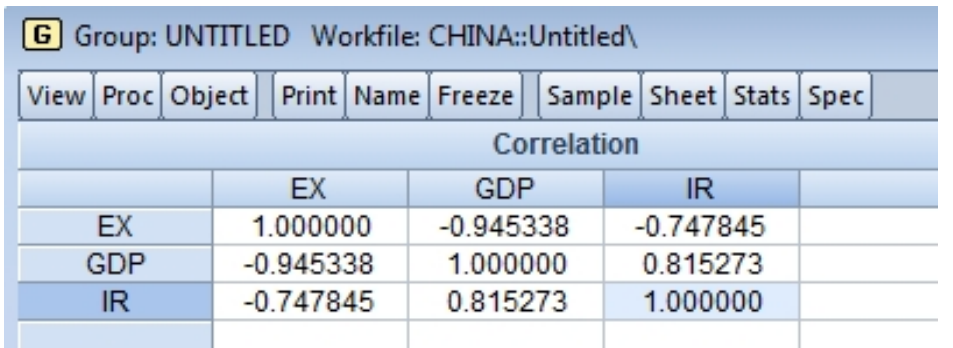

G Group: UNTITLED Workfile: USA::Untitled \

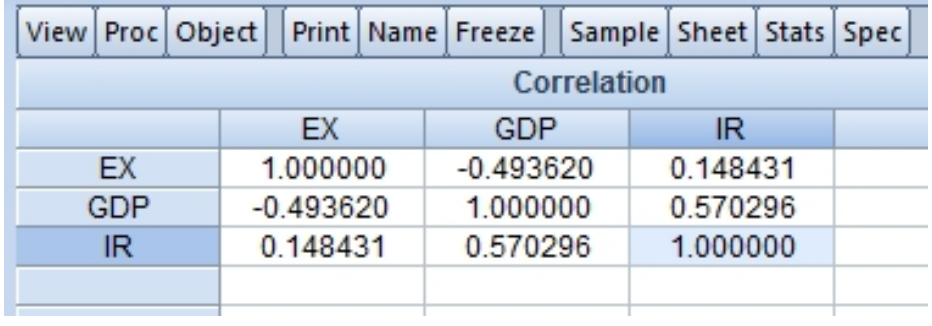

